\title{
Study of Low-grade Chronic Inflammatory Markers in Men with Central Obesity: Cathepsin S was Correlated with Waist Circumference
}

\author{
Adriana Todingrante ${ }^{1,2}$, Mansyur Arief ${ }^{3}$, Uleng Bahrun ${ }^{3}$, Ferry Sandra $^{4,5, *}$ \\ 'Postgraduate Program in Clinical Biochemistry, Hasanuddin University, Jl. Perintis Kemerdekaan Km.10, Makassar, Indonesia \\ ${ }^{2}$ Prodia Clinical Laboratory, J1. Sam Ratulangi No.72, Manado, Indonesia \\ ${ }^{3}$ Faculty of Medicine, Hasanuddin University, Jl.Perintis Kemerdekaan Km.10, Makassar, Indonesia \\ ${ }^{4}$ Prodia Clinical Laboratory, Jl. Kramat Raya No.150, Jakarta, Indonesia \\ ${ }_{5}^{5}$ Department of Biochemistry and Molecular Biology, Faculty of Dentistry, Trisakti University, Jl. Kyai Tapa No.260, Jakarta, Indonesia \\ ${ }^{*}$ Corresponding author. E-mail: ferrysandra@gmail.com
}

\section{Abstract}

B ACKGROUND: There is a prevalence increase of overweight and obesity in Indonesia. Central obesity can lead a variety of chronic diseases through the inflammatory process. There are some markers for low-grade chronic inflammatory, such as cathepsin S, high sensitivity C-reactive protein (hs-CRP), interleukin-1beta (IL-1 $\beta$ ). To our current interest that central obesity can lead to various chronic diseases through the inflammatory process, we conducted a study to investigate correlation of Cathepsin S, hs-CRP, IL-1 $\beta$ in men with central obesity.

METHODS: A cross-sectional study was conducted. Seventy-eight selected subjects were examined to collect anthropometric data and prepared for sample collection. Collected samples were processed for the following biochemical analyses: fasting glucose, high density lipoprotein (HDL)-cholesterol, triglyceride, serum glutamic oxaloacetic transaminase (SGOT), serum glutamate pyruvate transaminase (SGPT), cathepsin S, hs-CRP, and IL-1 $\beta$. Data distribution and variable correlation were then statistically analyzed.

RESULTS: There were significant correlations between waist circumference (WC) and cathepsin $\mathrm{S}(p=0.030$; $\mathrm{r}=0.214)$, hs-CRP and cathepsin $\mathrm{S}(p=0.007 ; \mathrm{r}=0.276)$, triglyceride and IL-1 $\beta(p=0.019 ; \mathrm{r}=-0.235), \mathrm{WC}$ and systolic blood pressure (SBP) $(p=0.003 ; \mathrm{r}=-0.312), \mathrm{WC}$ and fasting glucose $(p=0.000 ; \mathrm{r}=0.380), \mathrm{WC}$ and body mass index (BMI) $(p=0.000 ; \mathrm{r}=0.708)$.

CONCLUSION: Our study showed that cathepsin S was correlated with central obesity, suggesting that cathepsin S

\begin{abstract}
Abstrak

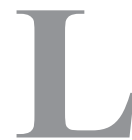

ATAR BELAKANG: Prevalensi kelebihan berat badan dan obesitas semakin meningkat di Indonesia. Obesitas sentral dapat menimbulkan berbagai penyakit kronik melalui proses inflamasi. Terdapat beberapa penanda inflamasi kronik derajat rendah, seperti cathepsin S, high sensitivity C-reactive protein (hs-CRP), interleukin-1-beta (IL-1 $\beta$ ). Terkait ketertarikan kami pada saat ini mengenai obesitas yang dapat menyebabkan berbagai penyakit kronik, maka kami melakukan studi untuk mengetahui korelasi cathepsin $S$, hs-CRP, IL-1 $\beta$ pada pria dengan obesitas sentral.
\end{abstract}

METODE: Penelitian ini menggunakan metode potong lintang. Tujuh puluh delapan subyek dilakukan pemeriksaan untuk mendapatkan data antropometrik dan persiapan pengumpulan sampel. Sampel kemudian diproses dan dilakukan analisa biokimia sebagai berikut: glukosa puasa, high density lipoprotein (HDL) kolesterol, trigliserida, serum glutamic oxaloacetic transaminase (SGOT), serum glutamate pyruvate transaminase (SGPT), cathepsin $S$, hs-CRP, dan IL-1 $\beta$. Kemudian, dilakukan analisa statistik terhadap distribusi data dan korelasi variabel.

HASIL: Didapatkan hasil korelasi bermakna antara lingkar pinggang (LP) dan cathepsin $S(p=0,030 ; \mathrm{r}=0,214)$, hsCRP dan cathepsin $S(p=0,007 ; \mathrm{r}=0,276)$, trigliserida dan IL-1 $\beta(p=0,019 ; \mathrm{r}=-0,235)$, LP dan tekanan darah sistolik $(p=0,003 ; \mathrm{r}=-0,312)$, LP dan glukosa puasa $(p=0,000$; $\mathrm{r}=0,380)$, LP and indeks berat badan $(p=0,000 ; \mathrm{r}=0,708)$.

KESIMPULAN: Penelitian ini memperlihatkan bahwa 
could be a potential inflammatory marker in central obesity in the future.

KEYWORDS: obesity, inflammation, hs-CRP, cathepsin S, IL-1 $\beta$, waist circumference

Indones Biomed J. 2013; 5(2): 115-20 cathepsin $S$ berkorelasi bermakna dengan obesitas sentral, sehingga cathepsin $S$ dapat diusulkan sebagai salah satu penanda inflamasi pada obesitas sentral yang berpotensi di masa yang akan datang.

KATA KUNCI: obesitas, Inflamasi, hs-CRP, cathepsin $S$, IL-1 $\beta$, lingkar pinggang

\section{Introduction}

Currently, there is an increase in the prevalence of overweight and obesity in the whole world as a negative consequence of increasing economic development in AsiaPacific countries. The World Health Organization estimates that 1 billion people overweight and 300 million are defined as obese. Based on Indonesia Family Life Survey conducted in population of 20,593 individuals in the year of 2000 , the prevalence of obesity (body mass index (BMI) $\geq 30 \mathrm{~kg} / \mathrm{m}^{2}$ ) in Indonesia was around $1.3 \%$ in male and $4.5 \%$ in female. National prevalence of general obesity for population over the age of 15 in Indonesia was estimated at $19.1 \%(8.8 \%$ overweight and $10.3 \%$ obese) where as in specific the prevalence of central obesity was $18.8 \%$. Indonesia national obesity prevalence is higher in female $(23.8 \%)$ than male $(13.9 \%)$. Based on province, the highest prevalence of central obesity was North Sulawesi (31.5\%), followed by Gorontalo (27\%) and Jakarta (27.9\%), respectively.(1) Prevalence increase of central obesity has an impact on the emergence of various degenerative diseases. Central obesity is associated with increased metabolic syndrome(2), atherosclerosis(3), cardiovascular disease (4,5), diabetes type $2(6,7)$, gallstones(8), impaired of pulmonary function(9), hypertension and dyslipidemia(10).

Adipokine plays an important role in the regulation of local and systemic metabolism, which indicate the presence of endocrine activity. Therefore, not only as a repository of fat but adipose tissue is an active endocrine organ that secretes various adipokines, which triggers inflammatory changes in the liver, systemic inflammation and atherosclerosis. $(11,12)$ Several studies show obesity is also associated with lowgrade chronic inflammatory conditions in adipose tissue, which was characterized by infiltration of macrophages and inflammatory gene expression. Weight loss in obese subjects may reduce pro-inflammatory molecules, thereby improving inflammatory status.(13)

Cathepsin $\mathrm{S}$ was reported to be reduced along with the weight loss.(14) Cathepsin S mRNA and serum were reported to have positive correlation with BMI and decreased after gastric surgery and weight loss. It has been shown previously, in cell culture experiment, each cathepsin $\mathrm{S}, \mathrm{L}$ or K suppressed the ability of humans to differentiate pre-adipocyte by blocking the degradation of extracellular fibronectin. Cell culture studies in animals showed that this protease increased adipogenesis and glucose hemostasis effect. Cathepsin L, S, and K are found in human adipose tissue with different expression patterns.(15)

Smooth muscle cells could synthesize human coronary arteries C-reactive protein (CRP) due to stimulation of inflammatory cytokines. Under stimulation of inflammatory cytokines, adipocyte could produce CRP. Induction may be increase due to the presence of interleukin (IL)- $1 \beta$ and IL-6. IL-1 $\beta$ genes control the expression of acute phase proteins through activation of the transcription factors: signal transducer and activator of transcription 3 (STAT3) and nuclear factor $\kappa \mathrm{B}$ (NF- $\kappa \mathrm{B})$. (16) IL-1 $\beta$ is a pro-inflammatory cytokine involved in pain, inflammation and autoimmune conditions(17), produced mainly by myeloid cells(18). Cathepsin S may be regulated, expressed and induced by cytokines IL-1 $\beta$, interferon gamma (IFN- $\gamma$ ) and tumor necrosis factor- $\alpha$ (TNF- $\alpha)$.(19)

To our current interest that central obesity can lead to various chronic diseases through the inflammatory process, we conducted a study to investigate correlation of inflammatory markers such as cathepsin S, IL-1 $\beta$, high sensitivity CRP (hs-CRP) in men with central obesity.

\section{Methods}

\section{Study Design and Subject Selection}

A cross-sectional study was conducted at Prodia Clinical Laboratory in Manado and Jakarta. The study protocol was approved by the Health Research Ethics Committee of the Faculty of Medicine Hasanuddin University (no. UH13030111). All written informed consents were collected accordingly. Initially, subjects, in the age of 30-60 years, completed a questionnaire related to medical history, exercise, medicine intake, smoking habit and alcohol intake. Men with central obesity was determined based on International Diabetes Federation 2005 criteria, that waist circumference $(\mathrm{WC}) \geq 90 \mathrm{~cm}$. 


\section{Sample Collection}

All subjects were examined after an overnight fasting for 1012 hours. Measurement of anthropometric parameters (WC $\geq 90 \mathrm{~cm}$, height, weight, blood pressure) and biochemical variable as follows: concentration of fasting glucose, high density lipoprotein (HDL)-cholesterol, triglyceride, serum glutamic oxaloacetic transaminase (SGOT), serum glutamate pyruvate transaminase (SGPT), hs-CRP, cathepsin S and IL$1 \beta$. Fasting serum samples were obtained and kept at $-20^{\circ} \mathrm{C}$. Subjects with hs-CRP $\geq 10 \mathrm{mg} / \mathrm{L}$ or SGOT/SGPT more than 5 times normal value, were excluded.

\section{Biochemical Analysis}

HDL cholesterol and triglyceride were measured with homogeneus enzymatic method. Fasting plasma glucose was measured with hexokinase method. SGOT and SGPT were measured with the International Federation of Clinical Chemistry method without pyridoxal phospate activation. All of above methods were performed by using Cobas
501 (Roche Diagnostics, Mannheim, Germany) in Prodia Laboratory, Manado. Level of hs-CRP was measured with immunoturbidimetric method using Cobas Integra (Roche Diagnostics). For detection of Cathepsin S, Human Total Cathepsin S ELISA Kit (Aviscera Bioscience, Santa Clara, CA) was used. For IL-1 $\beta$ detection, Human IL-1 beta/IL-1F2 Quantikine HS ELISA Kit (R\&D Systems, Minneapolis, $\mathrm{MN}$ ) was used. ELISA was performed using Microplate Reader 680 series (Bio-Rad Laboratories, Hercules, CA) in Prodia Laboratory Jakarta. All assays were performed according to kit manuals.

\section{Statistical Analysis}

Statistical analysis was conducted using IBM SPSS for Windows version 19.0 (IBM Corp., Armonk, NY). Normality of continuous variable distribution was analyzed with Kolmogorov-Smirnov test. Meanwhile variable correlation was analyzed with Spearman correlation analysis. $p$-value of $\leq 0.05$ was considered as statistically significant.

Table 1. Anthropometric characteristics

\begin{tabular}{lccccc}
\hline Characteristics & Mean \pm SD & Median & Min & Max & Range \\
\hline Age (year) & $46.33 \pm 7.88$ & 48.00 & 30.00 & 60.00 & 31.00 \\
WC (cm) & $102.40 \pm 7.58$ & 102.00 & 91.00 & 130.00 & 39.00 \\
Weight $(\mathrm{kg})$ & $80.91 \pm 12.59$ & 78.05 & 58.00 & 118.40 & 60.40 \\
Height $(\mathrm{cm})$ & $166.66 \pm 7.93$ & 166.00 & 145.00 & 185.00 & 40.00 \\
BMI $\left(\mathrm{kg} / \mathrm{m}^{2}\right)$ & $30.34 \pm 4.61$ & 29.38 & 21.83 & 44.56 & 22.73 \\
DBP $(\mathrm{mmHg})$ & $8282 \pm 7.50$ & 80.00 & 70.00 & 105.00 & 35.00 \\
SBP $(\mathrm{mmHg})$ & $122.50 \pm 10.53$ & 120.00 & 105.00 & 170.00 & 65.00 \\
\hline
\end{tabular}

DBP: diastolic blood pressure; SBP: systolic blood pressure; Min: minimum; Max: maximum

Table 2. Biochemical characteristics

\begin{tabular}{lrrrrr}
\multicolumn{1}{c}{ Characteristics } & Mean $\pm \mathbf{C V}$ & Median & Min & Max & Range \\
\hline SGOT (U/L) & $27.18 \pm 11.09$ & 24.00 & 11.00 & 76.00 & 65.00 \\
SGPT (U/L) & $41.27 \pm 26.12$ & 34.00 & 9.00 & 140.00 & 131.00 \\
Fasting Glucose (mg/dL) & $108.96 \pm 6.07$ & 99.00 & 79.00 & 298.00 & 219.00 \\
HDL-C (mg/dL) & $42.00 \pm 8.18$ & 40.00 & 31.00 & 68.00 & 37.00 \\
Triglyceride (mg/dL) & $159.35 \pm 9.17$ & 138.50 & 58.00 & 433.00 & 375.00 \\
hs-CRP (mg/L) & $2.85 \pm 2.34$ & 2.10 & 0.30 & 9.80 & 9.50 \\
Cathepsin S (pg/mL) & $9.34 \pm 0.23$ & 9.33 & 8.68 & 9.85 & 1.16 \\
IL-1 $\beta(\mathrm{pg} / \mathrm{mL})$ & $10.31 \pm 21.08$ & 0.42 & 0.04 & 57.00 & 56.96 \\
\hline
\end{tabular}

Min: minimum; Max: maximum 
Table 3. Data distribution

\begin{tabular}{lcc}
\hline Characteristics & $\begin{array}{c}\text { Kolmogorov- } \\
\text { Smirnov Z }\end{array}$ & $\boldsymbol{p}$-value \\
\hline Age & 0.853 & 0.461 \\
WC & 0.959 & 0.317 \\
Weight & 1.015 & 0.255 \\
Height & 0.619 & 0.837 \\
BMI & 0.941 & 0.339 \\
DBP & 2.427 & 0.000 \\
SBP & 2.187 & 0.000 \\
SGOT & 1.642 & 0.000 \\
SGPT & 1.592 & 0.013 \\
Fasting Glucose & 2.534 & 0.000 \\
HDL-C & 1.306 & 0.066 \\
Triglyceride & 0.729 & 0.005 \\
hs-CRP & 1.503 & 0.022 \\
Cathepsin S & 0.606 & 0.856 \\
IL-1 $\beta$ & 3.804 & 0.000 \\
\hline
\end{tabular}

\section{Results}

This study was conducted from April to May 2012. Seventyeight subjects were selected. Anthropometric characteristics were shown in Table 1. Meanwhile biochemical characteristics were shown in Table 2, and normality of continuous variable distribution were shown in Table 3.

Based on Spearman correlation analysis, significant correlated biochemical characteristics were WC with cathepsin S, hs-CRP with cathepsin S, triglyceride with IL$1 \beta$, WC with SBP, WC with fasting glucose, and WC with BMI (Table 4).

\section{Discussion}

Our study was conducted to investigate the relationship between central obesity with inflammation, represented by IL-1 $\beta$, cathepsin $\mathrm{S}$ and hs-CRP as markers of inflammation. Only men were included in this study to prevent possibility of bias, since some studies suggested that concentration of hs-CRP were influenced by gender.(20,21)

Previous studies showed that local IL- $1 \beta$ in adipocytes and hepatocytes contributed to accumulation of fatty liver in obesity. Weight loss caused decreased expression of IL$1 \beta$ in the subcutaneous fat and liver.(22) However, in our current study, we did not find significant correlation of WC with IL-1 $\beta$. We suggest a large subject number with bigger WC differences to be studied in order to confirm our current result.

In our study, WC was significantly correlated with cathepsin S, This supports some reports that suggest men with $\mathrm{WC} \geq 90 \mathrm{~cm}$ linked to low and chronic inflammatory process, which is characterized by a positive correlation to the inflammatory markers. $(23,24)$ Cathepsin S was reported by Taleb, et al., to have strong correlation with BMI at the mean of $50 \mathrm{~kg} / \mathrm{m}^{2}$.(25) Since in our study, only a maximum of $30.34 \mathrm{~kg} / \mathrm{m}^{2}$ BMI, less bulky than the subjects in Taleb study, therefore we found weak correlation between BMI and cathepsin S. Our results showed that WC is more related to the risk of metabolic disorders and cardiovascular disease than BMI which pertaining to peripheral obesity.(26)

We found a significant correlation between hs-CRP with cathepsin $\mathrm{S}$, which is in accordance to a report showing the interplay between the activity of cathepsin $\mathrm{S}$ with hsCRP and IL-6 even in normal individuals.(21) However, no significant correlation was found between IL-1 $\beta$ and cathepsin S, suggesting that the developing inflammatory allegedly through other mechanisms. Other pathways on the expression of cathepsin S, such as IL-1 receptor antagonist, produced by subcutaneous white adipose tissue, can bind to the IL-1 receptor to compete pro-inflammatory IL-1 ( $\alpha$ and $\beta) .(27,28)$ Further study is needed to investigate underlying mechanism of cathepsin $\mathrm{S}$ in men with central obesity.

\section{Conclusion}

Our study result showed significant correlation between Cathepsin S and central obesity. Cathepsin S could be a potential as inflammation marker in central obesity. Further study is needed to determine underlying mechanism of Cathepsin S in men with central obesity.

\section{Acknowledgement}

We thank the Prodia Education and Research Institute for the invaluable support in this study. 
Table 4. Correlation of parameters

\begin{tabular}{|c|c|c|c|c|c|}
\hline Parameter & & WC & hs-CRP & Cathepsin $\mathrm{S}$ & IL-1及 \\
\hline \multirow{2}{*}{ WC } & Correlation (r) & 1.000 & 0.153 & 0.214 & 0.107 \\
\hline & Significant $(p)$ & - & 0.091 & $0.030^{*}$ & 0.176 \\
\hline \multirow{2}{*}{ hs-CRP } & Correlation (r) & 0.153 & 1.000 & 0.276 & 0.126 \\
\hline & Significant $(p)$ & 0.091 & - & $0.007 * *$ & 0.137 \\
\hline \multirow{2}{*}{ Cathepsin S } & Correlation (r) & 0.214 & 0.276 & 1.000 & 0.040 \\
\hline & Significant $(p)$ & $0.030^{*}$ & $0.007 * *$ & - & 0.363 \\
\hline \multirow{2}{*}{ IL- $1 \beta$} & Correlation (r) & 0.107 & 0.126 & 0.040 & 1.000 \\
\hline & Significant $(p)$ & 0.176 & 0.137 & 0.363 & - \\
\hline \multirow{2}{*}{ HDL } & Correlation (r) & -0.085 & -0.076 & 0.075 & 0.012 \\
\hline & Significant $(p)$ & 0,230 & 0.255 & 0.256 & 0.460 \\
\hline \multirow{2}{*}{ Triglyceride } & Correlation (r) & 0.108 & 0.031 & 0.146 & -0.235 \\
\hline & Significant $(p)$ & 0.174 & 0.393 & 0.100 & $0.019^{*}$ \\
\hline \multirow{2}{*}{ SBP } & Correlation (r) & 0.312 & -0.114 & 0.175 & -0.042 \\
\hline & Significant $(p)$ & $0.003 * *$ & 0.160 & 0.062 & 0.358 \\
\hline \multirow{2}{*}{ DBP } & Correlation (r) & 0.129 & -0.018 & 0.154 & -0.066 \\
\hline & Significant $(p)$ & 0.130 & 0.439 & 0.089 & 0.284 \\
\hline \multirow{2}{*}{ Fasting glucose } & Correlation (r) & 0.380 & -0.044 & 0.046 & 0.120 \\
\hline & Significant $(p)$ & $0.000 * *$ & 0.351 & 0.344 & 0.149 \\
\hline \multirow{2}{*}{ BMI } & Correlation (r) & $0.708 * *$ & 0.195 & 0.162 & 0.148 \\
\hline & Significant $(p)$ & 0.000 & 0.087 & 0.157 & 0.196 \\
\hline
\end{tabular}

*correlation at significant level of $\mathrm{p} \leq 0.05$; ** correlation at significant level of $\mathrm{p} \leq 0.01$

\section{References}

1. Riset Kesehatan Dasar. Badan Penelitian dan Pengembangan Kesehatan. Departemen Kesehatan Republik Indonesia; Jakarta: Riskesdas; 2007. [cited November 2011]. Available from: http:// www.riskesdas.litbang.depkes.go.id/.

2. Shen W, Punyanitya M, Chen J, Gallagher D, Albu J, Pi-Sunyer X, et al. Waist circumference correlates with metabolic syndrome indicators better than percentage fat. Obesity. 2006; 14: 727-36.

3. Lee CD, Jacobs DR, Schreiner PJ, Iribarren C, Hankinson A. Abdominal obesity and coronary artery calcification in young adults: the Coronary Artery Risk Development in Young Adults (CARDIA) Study. Am J Clin Nutr. 2007; 86: 48-54.

4. Baik I, Ascherio A, Rimm EB, Giovannucci E, Spiegelman D, Stampfer MJ, et al. Adiposity and mortality in men. Am J Epidemiol. 2000; 152: 264-71.

5. Wildman RP, Gu D, Reynolds K, Duan X, Wu X, He J. Are waist circumference and body mass index independently associated with cardiovascular disease risk in Chinese adults? Am J Clin Nutr. 2005; 82: 1195-202.

6. Wang Y, Rimm EB, Stampfer MJ, Willett WC, Hu FB. Comparison of abdominal adiposity and overall obesity in predicting risk of type 2 diabetes among men. Am J Clin Nutr. 2005; 81: 555-63.

7. Krishnan S, Rosenberg L, Djousse L, Cupples LA, Palmer JR. Overall and central obesity and risk of type 2 diabetes in U.S. black woman. Obesity (Silver Spring). 2007; 15: 1860-6.

8. Tsai CJ, Leitzmann MF, Willett WC, Giovannucci EL. Prospective study of abdominal adiposity and gallstone disease in US men. Am J Clin Nutr. 2004; 80: 38-44.

9. Chen Y, Rennie D, Cormier YF, Dosman J. Waist circumference is associated with pulmonary function in normal-weight, overweight, and obese subjects. Am J Clin Nutr. 2007; 85: 35-9.

10. Barbagallo CM, Cavera G, Sapienza M, Noto D, Cefalu AB, Pagano M. et al. Prevalence of overweight and obesity in a rural southern Italy population and relationships with total and cardiovascular mortality: the ventimiglia di Sicilia project. Int J Obes Relat Metab 
Disord. 2001; 25: 185-90.

11. Gnacińska M, Małgorzewicz S, Guzek M, Lysiak-Szydłowska W, Sworczak K. Adipose tissue activity in relation to overweight or obesity. Endrokrynol Pol. 2010; 61: 160-8.

12. Zhang H, Cui J, Zhang C. Emerging role of adipokines as mediators in atherosclerosis. World J Cardiol. 2010; 2: 370-6.

13. van Dijk SJ, Feskens EJ, Bos MB, Hoelen DW, Heijligenberg R, Bromhaar MG, et al. A saturated fatty acid-rich diet induces an obesity-linked proinflammatory gene expression profile in adipose tissue of subjects at risk of metabolic syndrome. Am J Clin Nutr. 2009; 90: 1656-64.

14. Ärnlőv J. Cathepsin S as a biomarker: where are we now and what are the future challenges? Biomark Med. 2012; 6: 9-11.

15. Naour N, Rouault C, Fellahi S, Lavoie ME, Poitou C, Keophiphath $\mathrm{M}$, et al. Cathepsin in human obesity: changes in energy balance predominantly affect cathepsin $\mathrm{S}$ in adipose tissue and in circulation. J Clin Endocrinol Metab. 2010; 95: 1861-8.

16. Black S, Kushner I, Salmos D. C-reactive Protein. J Biol Chem. 2004; 279: 48487-90.

17. Ren K, Torres R. Role of interleukin-1 $\beta$ during pain and inflammation. Brain Res Rev. 2009; 60: 57-64.

18. Carey N, Lumeng CN, Saltiel AR. Inflammatory links between obesity and metabolic disease. Clin Invest. 2011; 121: 2111-17.

19. de Nooijer R, Bot I, von der Thusen JH, Leeuwenburgh MA, Overkleeft HS, Kraaijeveld AO, et al. Leukocyte cathepsin S is a potent regulator of both cell and matrix turnover in advanced atherosclerosis. Arterioscler Thromb Vasc Biol. 2009; 29: 188-94.

20. Chiriboga DE, Ma Y, Li W, Stanek III EJ, bert He'JR, Merriam PA, et al. Seasonal and sex variation of high-sensitivity c-reactive protein in healthy adults: a longitudinal study. Clin Chem. 2009; 55: 31321.

21. Jobs E, Rise'rus U, Ingelsson E, Helmersson J, Nerpin E, Jobs M, et $a l$. Serum cathepsin $\mathrm{S}$ is associated with serum c-reactive protein and interleukin-6 independently of obesity in elderly male. J Clin Endocrinol Metab. 2010; 95: 4460-4.

22. Nov O, Shapiro H, Ovadia H, Tarnovscki T, Dvir I, Shemesh E, et al. Interleukin-1 $\beta$ regulates fat-liver crosstalk in obesity by auto-paracrine modulation of adipose tissue inflammation and expandability. PLoS One. 2013; 8: e5362624.

23. Wellen KE, Hotamisligil GS. Obesity induces inflammatory changes in adiposa tissue. J Clin Invest. 2003; 112: 1785-8.

24. Fain JN. Release of inflammatory mediators by human adipose tissue is enhanced in obesity and primarily by the nonfat cells: a review. Mediators inflamm 2010; 18: 890-96.

25. Taleb S, Lacasa D, Bastard JP, Poitou C, Cancello R, Pelloux V, et al. Cathepsin S, a novel biomarker of adiposity: relevance to atherogenesis. FASEB J. 2005; 19: 1540-2.

26. Wang Y, Rimm EB, Stampfer MJ, Willett WC, Hu FB. Comparison of abdominal adiposity and overall obesity in predicting risk of type 2 diabetes among male. Am J Clin Nutr. 2005; 81: 555-63.

27. Jung C, Gerdes N, Fritzenwanger M, Figulla RH. Circulating levels of interleukin-1 family cytokines in overweight adolescents. Mediators of Inflamm. 2010; 2010: 958403.

28. Grant WR, Dixit VD. Mechanisms of disease: inflammasome activation and the development of type 2 diabetes. Front Immunol. 2013; 4: 50. doi: 10.3389/fimmu.2013.00050. 